Available online at : http://journal.unj.ac.id/unj/index.php/gjik

Gladi : Jurnal Ilmu Keolahragaan 10 (02) 2019, 79 - 88

Permalink/DOI: https://doi.org/10.21009/GJIK.102.02

\title{
PENGARUH POWER LENGAN, PANJANG LENGAN DAN KOORDINASI MATA TANGAN TERHADAP KETERAMPILAN PASSING BAWAH DALAM PERMAINAN BOLA VOLI PADA SISWA SMK NEGERI 10 MAKASSAR
}

\author{
Alimin 1 \\ ${ }^{1}$ Pendidikan Olahraga, Program Pascasarjana, Universitas Negeri Makassar \\ Kampus Gunungsari Baru, Jl. Bonto Langkasa, Makassar-90222 \\ Corresponding Email : aliminali012@gmail.com
}

\begin{abstract}
Abstrak : Penelitian ini bertujuan untuk mengetahui pengaruh power lengan, panjang lengan serta koordinasi mata tangan terhadap keterampilan passing bawah pada cabang olahraga voli. Penelitian ini merupakan penelitian deskriptif dengan menggunakan desain analisis jalur dengan pengelolaan secara statistik menggunakan aplikasi SPSS versi 21.00 dan taraf signifikansi 0.05 atau $95 \%$. Populasi dalam penelitian ini adalah seluru siswa SMK Negeri 10 Makassar yang ikut dalam kegiatan ekstrakurikuler bola voli sebanyak 30 orang. Dan sampel dalam penelitian ini adalah peneliti mengambil seluruh populasi sebanyak 30, teknik pengambilan sampel yaitu dengan teknik purposive sampling. Hasil penelitian dari hasil pengujian analisis regresi struktur 1 dan struktur 2 menunjukkan bahwa pengaruh langsung power lengan terhadap koordinasi mata-tangan sebesar 0,844. Pengaruh langsung panjang lengan-terhadap koordinasi mata-tangan sebesar 0.266. Pengaruh langsung power lengan terhadap keterampilan passing bawah sebesar 0.845. Pengaruh langsung panjang lengan terhadap keterampilan passing bawah sebesar 0.429. Pengaruh langsung koordinasi mata-tangan terhadap keterampilan passing bawah sebesar 0,765. Dilihat dari nilai $\alpha$ 0,05 maka pengaruh langsung power lengan, panjang lengan terhadap koordinasi mata-tangan dan power lengan, panjang lengan, koordinasi mata-tangan terhadap keterampilan passing bawah diterima karena nilai signifikansi di bawah $\alpha 0,05$. Hasil penelitian dari nilai standardized coefficients beta. Pengaruh tidak langsung power lengan melalui koordinasi mata-tangan terhadap keterampilan passing bawah sebesar 0,645 lebih kecil dari pengaruh langsung power lengan terhadap keterampilan passing bawah sebesar 0,845. Pengaruh tidak langsung panjang lengan melalui koordinasi mata-tangan terhadap keterampilan passing bawah sebesar 0.203 lebih kecil dari pengaruh langsung panjang lengan terhadap keterampilan passing bawah sebesar 0,429.
\end{abstract}

Kata Kunci: power lengan, panjang lengan, koordinasi mata-tangan dan keterampilan passing bawah.

Abstract: The study aims at examining the influence of arms power and arm's length directly on lower passing skills, and the indirect influence of arms power and arm's length on lower passing skills based on yeast-hands coordination. The study is descriptive research by using path analysis design which is processed statistically using SPSS version 21.00 application at the significant level 0.05 or $95 \%$. The populations of the study were students at SMKN 10 Makassar who took extracurricular in volleyball with 30 students. The samples were all population with 30 students taken by employing purposive sampling technique. The results of the study from regression analysis of structure 1 and 2 indicated that the direct influence of arms power on eyes-hand coordination is 0.844 . The direct influence of arm's length on eyes-hands coordination is 0.266 . The indirect influence arms power on lower passing skills is 0.845. The direct influence of arm's length on lower passing skills is 0.429. The direct influence of eyes-hands coordination on lowers passing skills is 0.765. Based on the value of $\alpha$ 0.05, the direct influence of arms power, arm's length on eyes-hands coordination and arms power, arm's length, eyes-hands coordination on lower passing skills are accepted because the significant value is lower $\alpha 0.05$. The results of the study from the standardized coefficients beta value indicated that the indirect influence of arms power through eyes-hands coordination on lower passing skills is 0.645 which is smaller than the direct influence of arms power on lower passing skills by 0.845. The indirect influence of arm's length through eyes-hands coordination on lower passing skills is 0.203 which is smaller than the direct influence of arm 's length of lower passing skills by 0.429.

Keywords: arms power, arm's length, eyes-hands coordination and lower passing skills. 


\section{PENDAHULUAN}

Permainan bola voli merupakan salah satu cabang olahraga yang sangat digemari oleh masyarakat Indonesia. Perhatian pemerintah terhadap bidang keolahragaan semakin meningkat terutama faktor-faktor pendukung untuk pencapaian prestasi baik di tingkat regional, nasional, maupun internasional.

Teknik dasar bola voli. Menurut rahmani (2014 : 115 dalam jurnal Rendy Abrasyi, Bambang Sujiono, Hernawan, 2018) dalam cabang olahraga bola voli terdapat beberapa teknik dasar diantaranya servis, passing, smash, dan blocking.

Menurut Peter Waite (2009 : 43 dalam jurnal rendy abrasyi, bambang sujiono, hernawan, 2018) passing is one of the most vital skills in the sport of volleyball; without it, you will have no offense. Passing adalah keterampilan yang paling sering digunakan dan diperlukan, tanpa adanya passing, permainan tidak akan berjalan dengan lancar pada permainan.

Salah satu teknik dasar permainan bola voli yang menjadi titik lemah pada saat permainan berlangsung adalah keterampilan passing bawah, padahal passing bawah memegang peranan penting dalam bertahan dan menyerang.

Passing bawah adalah umpan yang diberikan kepada teman satu tim yang menggunakan lengan yang lurus dan di kunci, telapak tangan menyilang, telapak tangan di tekan ibu jari dan telapak tangan menghadap ke atas. (rendy abrasyi, bambang sujiono, hernawan, 2018).

Berdasarkan pengamatan peneliti bahwa selain melakukan teknik dasar dengan baik dan benar, permasalahan yang sering terjadi dalam permainan bola voli adalah siswa di sekolah terkadang mengabaikan hal-hal yang berkontribusi dalam pelaksanaan passing bawah. Faktorfaktor tersebut antara lain kekuatan otot lengan, panjang lengan dan koordinasi mata tangan.

Dalam melakukan passing bawah pada permainan bola voli diperlukan lengan yang kuat, karena merupakan salah satu faktor keberhasilan dalam melakukan passing bawah. Kekuatan otot lengan adalah keterampilan otot lengan dalam mengembangkan tenaga maksimum dalam kontraksi yang maksimal untuk mengatasi beban atau hambatan. Kekuatan adalah keterampilan dari otot untuk mengatasi tahanan atau beban dalam menjalankan aktivitas. Tahanan dalam hal ini adalah bola yang diterima dengan passing bawah.

Menurut M. Sajoto (1988: 58) daya ledak atau Muscular power adalah "kemampuan seseorang untuk melakukan kekuatan maksimum dengan usaha yang dikerahkan dalam waktu sependek- 
pendeknya.". Dalam hal ini dapat dikemukakan bahwa, daya ledak atau power = kekuatan atau Force X kecepatan atau velocity $(\mathrm{P}=\mathrm{F} \times \mathrm{T})$ seperti gerak dalam tolak peluru, lompat tinggi dan gerakan lainnya yang bersifat explosive.

Koordinasi mata tangan yang baik turut menunjang keterampilan gerak dalam melakukan passing bawah pada permainan bola voli karena seseorang yang memiliki koordinasi yang baik mampu bergerak dengan mudah dan lancar dalam melakukan rangkaian gerakan, iramanya terkontrol dengan baik serta mampu melakukan gerakan yang efisien.

Koordinasi adalah menggabungkan sistem syaraf terpisah dengan mengubahnya menjadi suatu pola gerak yang efisien. Semakin kompleks suatu gerakan, maka semakin tinggi tingkat koordinasinya.

Bompa \& Tudor (1990, p. 56) menyatakan bahwa koordinasi adalah suatu komponen biomotorik yang sangat kompleks, saling berhubungan dengan kecepatan, kekuatan, daya tahan dan kulentukkan. Kecenderungan orang selama ini mengartikan koordinasi sebagai keterampilan seseorang untuk merangkai beberapa unsur gerakan menjadi suatu gerakan yang selaras dan sesuai dengan tujuannya.
Dalam pencapaian hasil passing bawah yang baik dalam permainan bola voli, selain memiliki kekuatan otot lengan dan koordinasi mata tangan yang baik, antropometri (panjang lengan) juga merupakan salah satu bagian yang sangat penting dalam pencapaian hasil gerak yang sempurna, terutama sekali menyangkut kapasitas raihan atau keterampilan menjangkau dalam sebuah aktivitas olahraga tertentu. Raihan dalam hal ini adalah keterampilan menjangkau bola voli pada saat melakukan passing bawah. Terutama dalam menjangkau bola liar yang jauh dan keras.

Menurut Suharno (1985:9) pemain bola voli yang baik harus memiliki antara lain anatomis yang baik, tinggi badan 180 $\mathrm{cm}$ ke atas untuk putra dan $160 \mathrm{~cm}$ ke atas untuk putri. Pendapat tersebut dipertegas oleh Yunus (1992, p. 35) bahwa penjelasan di atas mempunyai pemikiran bahwa ukuran panjang lengan menyesuaikan dengan tinggi badan. Semakin tinggi badan seseorang, maka ukuran lengan akan bertambah. Lebih lanjut Suharno (1985:9) menjelaskan bahwa tangan panjang dan ramping tetapi harus memiliki daya ledak yang tinggi untuk pukulan bola voli.

Oleh karena itu, untuk mencapai hasil passing bawah yang baik, bukan hanya menguasai teknik dengan benar tapi kita juga perlu memperhatikan komponen 
fisik, seperti kekuatan otot lengan, koordinasi mata tangan serta kondisi antropometri (panjang lengan).

Jadi keterampilan seorang pemain bola voli untuk memadukan unsur kekuatan otot lengan, koordinasi mata tangan yang didukung dengan panjang lengan yang baik pada saat melakukan passing bawah akan berpengaruh terhadap baik buruknya ayunan yang dihasilkan.

Dari teori di atas mendorong peneliti untuk mengadakan suatu penelitian yakni "Pengaruh Power Lengan, Panjang Lengan Dan Koordinasi Mata Tangan Terhadap Keterampilan Passing Bawah Dalam Permainan Bola Voli Pada Siswa SMK Negeri 10 Makassar".

\section{METODE}

Pada dasarnya metode merupakan teknik atau cara yang dipergunakan untuk mencari pembuktian secara ilmiah yang dilakukan secara sistematis dalam mengungkapkan dan memberi jawaban atas permasalahan yang dikemukakan dalam suatu penelitian, sehingga arah dan tujuan pengungkapan fakta atau kebenaran sesuai dengan apa yang ditemukan dalam penelitian.

Menurut Sugiyono (2017, p. 35) mengemukakan bahwa "variabel penelitian adalah segala sesuatu yang berbentuk apa saja yang ditetapkan oleh peneliti untuk dipelajari sehingga diperoleh informasi tentang hal tersebut, kemudian ditarik kesimpulannya.

Variabel dalam penelitian ini adalah power lengan (X1), panjang lengan (X2), koordinasi mata - tangan (X3) dan keterampilan passing bawah (Y). Power lengan adalah kemampuan otot lengan dalam mengembangkan tenaga maksimum dalam kontraksi yang maksimal dalam waktu yang sependek-pendeknya. Panjang lengan merupakan bagian dari struktur tubuh yang merupakan salah satu indikator penggerak bagi tubuh dalam melakukan gerak atau aktivitas termasuk dalam kegiatan olahraga.

Koordinasi adalah kemampuan seseorang dalam merangkai berbagai macam gerakan menjadi satu dalam satu satuan waktu dengan gerakan yang selaras dan sesuai dengan tujuan. Tingkat koordinasi atau baik tidaknya koordinasi gerak seseorang tercermin dalam kemampuannya untuk melakukan suatu gerakan secara mulus, tepat dan efisien. Passing bawah merupakan cara memainkan bola dengan menggunakan kedua lengan yang saling bertautan atau dengan satu lengan. Perkenaan bola pada passing bawah yaitu di atas pergelangan tangan.

Teknik pengumpulan data yang dipakai dalam penelitian ini adalah metode pengukuran dan tes yang merupakan suatu 
cara pengumpulan data untuk dianalisis. Teknik pengumpulan data merupakan salah satu langkah penting dalam penelitian karena akan dihubungkan dengan data yang diperoleh selama penelitian. Untuk memperoleh data yang sesuai dengan penelitian ini, maka teknik digunakan adalah metode survei ke kelapangan kemudian dilakukan kemudian dilakukan pengukuran dan tes. Penelitian ini dilaksanakan di SMK Negeri 10 Makassar.

\section{HASIL DAN PEMBASAHAN}

Tabel 1. Deskripsi data hasil Perhitungan (X1)

\begin{tabular}{lr}
\hline & (X1) \\
\hline $\mathrm{N}$ & 30 \\
Mean & 28.07 \\
Median & 28.00 \\
Std. Deviation & 2.625 \\
Variance & 6.892 \\
Range & 10 \\
Minimum & 24 \\
Maximum & 34 \\
Sum & 842 \\
\hline
\end{tabular}

Sumber: Analisis Data SPSS versi 21, 2018

Tabel 2. Deskripsi data hasil perhitungan (X2)

\begin{tabular}{lr}
\hline & (X2) \\
\hline $\mathrm{N}$ & 30 \\
Mean & 77.97 \\
Median & 78.50 \\
Std. Deviation & 4.694 \\
Variance & 22.033 \\
Range & 16
\end{tabular}

\begin{tabular}{lr} 
Minimum & 69 \\
Maximum & 85 \\
Sum & 2339 \\
\hline \multicolumn{2}{l}{ Sumber: Analisis Data SPSS versi 21,} \\
2018
\end{tabular}

Tabel 3. Deskripsi data hasil perhitungan (X3)

\begin{tabular}{lr}
\hline & $(\mathbf{X 3})$ \\
\hline $\mathrm{N}$ & 30 \\
Mean & 18.07 \\
Median & 18.00 \\
Std. Deviation & 2.149 \\
Variance & 4.616 \\
Range & 8 \\
Minimum & 14 \\
Maximum & 22 \\
Sum & 542 \\
\hline \multicolumn{2}{c}{ Sumber: Analisis Data SPSS versi 21, } \\
\multicolumn{2}{c}{ 2018 }
\end{tabular}

Tabel 4. Deskripsi data hasil perhitungan (Y)

\begin{tabular}{lr}
\hline & $(\mathbf{Y})$ \\
\hline $\mathrm{N}$ & 30 \\
Mean & 18.13 \\
Median & 18.00 \\
Std. Deviation & 1.889 \\
Variance & 3.568 \\
Range & 6 \\
Minimum & 15 \\
Maximum & 21 \\
Sum & 544 \\
\hline \multicolumn{2}{c}{ Sumber: Analisis Data SPSS versi 21, } \\
\multicolumn{2}{c}{ 2018 }
\end{tabular}

Adapun hasil pengujian normalitas data variabel power lengan, panjang lengan 
dan koordinasi mata - tangan terhadap keterampilan passing bawah siswa SMK Negeri 10 Makassar, dapat dilihat pada tabel berikut:

Tabel 5. Hasil Pengujian Normalitas data Variabel power lengan, panjang lengan, dan koordinasi mata-tangan terhadap keterampilan passing bawah dalam permainan bola voli pada siswa SMK

Negeri 10 Makassar.

\begin{tabular}{cccc}
\hline Variabel & KS-Z & $\begin{array}{c}\boldsymbol{P}- \\
\text { Value }\end{array}$ & $\boldsymbol{\alpha}$ \\
\hline X1 & 0.681 & 0.742 & 0.05 \\
X2 & 0.757 & 0.615 & 0.05 \\
X3 & 0.555 & 0.918 & 0.05 \\
Y & 0.603 & 0.860 & 0.05 \\
\hline
\end{tabular}

Pengujian hipotesis dari data setiap variabel yang dikemukakan pada hipotesis tersebut dilakukan dengan menggunakan dengan SPSS versi 21. Adapun hasil yang diperoleh dapat dilihat pada tabel koefisien persamaan struktural model I sebagai berikut:

Tabel 6. Hasil analisis multivariate regresi struktur 1 variabel power lengan terhadap koordinasi mata-tangan.

\begin{tabular}{cccc}
\hline Variabel & Beta & $\boldsymbol{P}$ & A \\
\hline X1 & \multirow{2}{*}{0,844} & 0,000 & 0,05 \\
X3 & & & \\
\hline X2 & & &
\end{tabular}

\begin{tabular}{llll}
$\mathrm{X} 3$ & & 0,010 & 0,05 \\
& 0,266 & & \\
\hline
\end{tabular}

Persamaan tabel 6 di atas dikatakan layak untuk digunakan karena nilai $P$ pada uji tersebut <0,05. Dari tabel koefisien Model Sub Struktur 1 di atas diperoleh nilai koefisien persamaan struktural untuk ariabel power lengan terhadap koordinasi ulata-tangan sebesar 0,844. Artinya terdapat pengaruh langsung yang signifikan power lengan terhadap koordinasi matatangan.

Persamaan di atas dikatakan layak untuk digunakan karena nilai $\mathrm{P}$ pada uji tersebut $<0,05$. Dari tabel koefisien Model Sub Struktur 1 di atas diperoleh nilai koefisien persamaan struktural untuk panjang lengan terhadap koordinasi matatangan sebesar 0,266. Artinya terdapat pengaruh langsung yang signifikan panjang lengan terhadap koordinasi mata-tangan.

Adapun hasil pengolahan data menggunakan SPSS versi 21 untuk hipotesis tersebut dapat dilihat pada tabel berikut:

Tabel 7. Hasil analisis multivariate regresi struktur 2 variabel power lengan, panjang lengan dan koordinasi matatangan terhadap keterampilan passing bawah.

\begin{tabular}{lrcr}
\hline Variabel & Beta & $\boldsymbol{P}$ & A \\
\hline $\mathrm{X} 1$ & 0,845 & 0,019 & 0,05
\end{tabular}




\begin{tabular}{llll}
$\mathrm{Y}$ & & & \\
\hline $\mathrm{X} 2$ & 0,429 & 0,037 & 0,05 \\
$\mathrm{Y}$ & & & \\
\hline $\mathrm{X} 3$ & 0,765 & 0,035 & 0,05 \\
$\mathrm{Y}$ & & & \\
\hline
\end{tabular}

a) Nilai koefisien persamaan struktural untuk variabel power lengan terhadap keterampilan passing bawah sebesar 0,845 dengan signifikan yang diperoleh adalah 0,019. Karena nilai signifikan lebih kecil dari $0,05(0,019<0,05)$ maka dapat diambil keputusan Ho ditolak. Artinya terdapat pengaruh langsung yang signifikan power lengan terhadap keterampilan passing bawah.

b) Nilai koefisien panjang lengan terhadap keterampilan passing bawah sebesar 0,429 dengan signifikan yang diperoleh adalah 0,037. Karena nilai signifikan lebih kecil dari $0,05(0,037<0,05)$ maka dapat diambil keputusan Ho ditolak. Artinya terdapat pengaruh langsung yang signifikan panjang lengan terhadap keterampilan passing bawah.

c) Nilai koefisien koordinasi mata-tangan terhadap keterampilan passing bawah sebesar 0,765 dengan signifikan yang diperoleh adalah 0,035. Karena nilai signifikan lebih kecil dari $0,05(0,035<$ 0,05) maka dapat diambil keputusan Ho ditolak. Artinya terdapat pengaruh langsung yang signifikan koordinasi mata-tangan terhadap keterampilan passing bawah.

Dalam desain analisis jalur terdapat pengaruh secara tidak langsung, maka hipotesis tersebut juga perlu diuji apakah memiliki pengaruh tidak langsung yang signifikan atau tidak memiliki pengaruh tidak langsung yang signifikan. Koefisien yang dapat menjelaskan pengaruh antar variabel ini adalah standardized coefficient beta.

Pada hipotesis keenam yaitu untuk mengetahui apakah ada pengaruh tidak langsung power lengan melalui koordinasi mata-tangan terhadap keterampilan passing bawah. Diketahui nilai koefisien beta pengaruh langsung power lengan terhadap koordinasi mata-tangan adalah 0,844 dan nilai koefisien beta pengaruh langsung terhadap koordinasi mata-tangan terhadap keterampilan passing bawah adalah 0,765. Maka nilai koefisien beta pengaruh tidak langsung power lengan melalui koordinasi mata-tangan terhadap keterampilan passing bawah adalah $(0,844 * 0,765=0,645)$. Dan hasil analisis multivariate dari variabel power lengan dengan variabel koordinasi mata-tangan diperoleh nilai sig sebesar 0,000 dan nilai koordinasi mata-tangan terhadap keterampilan passing bawah diperoleh nilai sig sebesar 0,035. Maka nilai sig pengaruh tidak langsung power 
lengan melalui koordinasi mata-tangan terhadap keterampilan passing bawah adalah $(0,000 * 0,035=0,000)$. Karena nilai sig lebih kecil dari 0,05. Sehingga dapat disimpulkan bahwa pengaruh power lengan cenderung berpengaruh secara langsung terhadap keterampilan passing bawah tanpa perlu melalui faktor koordinasi mata-tangan.

Pada hipotesis ketujuh yaitu untuk mengetahui apakah ada pengaruh tidak langsung panjang lengan melalui koordinasi mata-tangan terhadap keterampilan passing bawah. Diketahui nilai koefisien beta pengaruh langsung panjang lengan terhadap koordinasi matatangan adalah 0,266 dan nilai koefisien beta pengaruh langsung koordinasi mata-tangan terhadap keterampilan passing bawah adalah 0,765. Maka nilai koefisien beta pengaruh tidak langsung panjang lengan melalui koordinasi mata-tangan terhadap hasil keterampilan passing bawah adalah $(0,266 * 0,765=0,203)$. Dan hasil analisis multivariate dari variabel panjang lengan dengan variabel koordinasi mata-tangan diperoleh nilai sig sebesar 0,010 dan nilai koordinasi mata-tangan terhadap keterampilan passing bawah diperoleh nilai sig sebesar 0,035. Maka nilai sig pengaruh tidak langsung panjang lengan melalui koordinasi mata-tangan terhadap keterampilan passing bawah adalah
$(0,010 * 0,035=0,00035)$. Karena nilai sig lebih kecil dari 0,05 Sehingga dapat disimpulkan bahwa pengaruh panjang lengan cenderung berpengaruh secara langsung terhadap keterampilan passing bawah tanpa perlu melalui faktor koordinasi mata-tangan.

1. Ada pengaruh langsung power lengan terhadap koordinasi mata-tangan pada siswa SMK N 10 Makassar.

Dari hasil analisis data yang diperoleh ada tiga hal yang ditunjukkan. Pertama, nilai koefisien beta variabel power lengan terhadap koordinasi mata-tangan sebesar 0,844 . Kedua, nilai signifikansi yang diperoleh sebesar 0,000. Ketiga, nilai signifikan yang diperoleh lebih kecil dari a 0,05 $(0,000<0,05)$.

2. Ada pengaruh langsung panjang lengan terhadap koordinasi mata-tangan pada siswa SMK N 10 Makassar.

Dari hasil analisis data yang diperoleh ada tiga hal yang ditunjukkan. Pertama, nilai koefisien beta variabel panjang lengan terhadap koordinasi mata-tangan sebesar 0,266. Kedua, nilai signifikansi yang diperoleh sebesar 0,010. Ketiga, nilai signifikan yang diperoleh lebih kecil dari $\alpha \quad 0,05$ $(0,010<0,05)$. 
3. Ada pengaruh langsung power lengan terhadap keterampilan passing bawah pada siswa SMK N 10 Makassar.

Dari hasil analisis data yang diperoleh ada tiga hal yang ditunjukkan. Pertama, nilai koefisien beta variabel power lengan terhadap keterampilan passing bawah sebesar 0,845. Kedua, nilai signifikansi yang diperoleh sebesar 0,019. Ketiga, nilai signifikan yang diperoleh lebih kecil dari $\alpha 0,05$ $(0,019<0,05)$.

4. Ada pengaruh langsung panjang lengan terhadap keterampilan passing bawah pada siswa SMK N 10 Makassar.

Dari hasil analisis data yang diperoleh ada tiga hal yang ditunjukkan. Pertama, nilai koefisien beta variabel panjang lengan terhadap keterampilan passing bawah sebesar 0,429. Kedua, nilai signifikansi yang diperoleh sebesar 0,037. Ketiga, nilai signifikan yang diperoleh lebih kecil dari $\alpha 0,05$ $(0,037<0,05)$.

5. Ada pengaruh langsung koordinasi mata - tangan terhadap keterampilan passing bawah pada siswa SMK N 10 Makassar.

Dari hasil analisis data yang diperoleh ada tiga hal yang ditunjukkan. Pertama, nilai koefisien beta variabel koordinasi mata-tangan terhadap keterampilan passing bawah sebesar
0,765. Kedua, nilai signifikansi yang diperoleh sebesar 0,035. Ketiga, nilai signifikan yang diperoleh lebih kecil dari $\alpha 0,05(0,035<0,05)$.

\section{KESIMPULAN}

Berdasarkan hasil penelitian dan pembahasan yang telah dikemukakan, maka dapat ditarik beberapa kesimpulan. 1) Ada pengaruh langsung power lengan terhadap koordinasi mata-tangan pada siswa SMK Negeri 10 Makassar. 2) Ada pengaruh langsung panjang lengan terhadap koordinasi mata-tangan pada siswa SMK Negeri 10 Makassar. 3) Ada pengaruh langsung power lengan terhadap keterampilan passing bawah dalam permainan bola voli pada siswa SMK Negeri 10 Makassar. 4) Ada pengaruh langsung panjang lengan terhadap keterampilan passing bawah dalam permainan bola voli pada siswa SMK Negeri 10 Makassar. 5) Ada pengaruh langsung koordinasi mata-tangan terhadap keterampilan passing bawah dalam permainan bola voli pada siswa SMK Negeri 10 Makassar. 6) Ada pengaruh tidak langsung power lengan melalui koordinasi mata-tangan terhadap keterampilan passing bawah dalam permainan bola voli pada siswa SMK Negeri 10 Makassar. 7) Ada pengaruh tidak langsung panjang lengan melalui 
koordinasi mata-tangan terhadap keterampilan passing bawah dalam permainan bola voli pada siswa SMK Negeri 10 Makassar.

Berdasarkan kesimpulan tersebut di atas, maka dapat disarankan bagi para pembina atau guru olahraga, direkomendasikan bahwa kiranya dalam upaya untuk meningkatkan keterampilan passing bawah pada siswa atau atlet hendaknya memperhatikan beberapa unsur di luar teknik dasar passing bawah salah satunya adalah kondisi fisik. bagi para siswa, disarankan bahwa siswa perlu membekali diri dengan kondisi fisik yang baik agar lebih mudah meningkatkan prestasinya.

\section{DAFTAR PUSTAKA}

Ahmadi, N. (2007). Panduan Olahraga Bola Voli. Surakarta: Era Pustaka Utama.

Andi, R. (2012). Kontribusi Panjang Lengan, Kelentukan Pergelangan Tangan Terhadap Kemampuan Pukulan Dropshot Bulu Tangkis Mahasiswa Fik UNM. Jurnal Kajian Pendidikan Jasmani Kesehatan \& Rekreasi, 3(3).

Andy, N. (2017). Hubungan antara panjang lengan, kekuatan otot lengan dengan keterampilan passing bawah bola voli sma negeri 5 bandar lampung. Universitas Lampung.

Anwar, P. (2012). Pertumbuhan Dan Perkembangan Fisik Pendidikan Jasmani, Olahraga Dan Kesehatan. Makassar: Badan Penerbit Universitas Negeri Makassar.

Bompa, \& Tudor, O. (1990). Theory And Metodology of Training. Lowa: Kendal/Hunt Publishing Company.
Burhan, B. (2006). Metodologi penelitian kuantitatif. Jakarta: Kencana.

Durwachter, G. (2002). Belajar Dan Berlatih Sambil Bermai Bolavolley. Jakarta: Gramedia.

Halim, \& Ichsan, N. (2004). Tes dan pengukuran kesegaran jasmani. Makassar: Badan Penerbit Universitas Negeri Makassar.

Harsono. (1998). Coaching Dan Aspekaspek Psikologi Dalam Coaching. Jakarta: PT. Dirjen Dikti P2LPT.

Hikmad, H. (2012). Analisis Kemampuan Passing Bawah Dalam Permainan Bola Voli Pada Siswa Cokroaminoto Tamalanrea Makassar. Jurnal Pendidikan Kepelatihan Olahraga FIK UNM, 4(3).

Juliansyah, N. (2016). Metodologi Penelitian. Jakarta: Kencana.

Rendy Abrasyi, Bambang Sujiono, Hernawan, D. (2018). Model Latihan Passing Bawah Bola Voli Pada Siswa Sekolah Menengah Pertama. Journal Sport Area Penjaskesrek FKIP UIR, 2(3), 178.

Sugiyono. (2017). Metode penelitian kuantitatif, kualitatif dan $R \& D$. Bandung: Alfabeta.

Suharsimi, A. (1998). Prosedur Penelitian Suatu Pendekatan Praktik. Rineka Cipta.

Viera, \& Bonnie. (2004). Bola Voli Tingkat Pemula. Jakarta: PT. Raja Grafindo Persada.

Widiastuti. (2017). Teknik Dasar Bermain Bola Voli. Jakarta: PT Raja Grafindo Persada.

Winarno. (2013). Teknik Dasar Bermain Bola Voli. Malang: Universitas Negeri Malang (UM Press).

Yunus, M. (1992). Olahraga Pilihan Bolavoli. Jakarta: Jakarta: Depdikbud, Dirjendikti, PPTK. 